\title{
Comparative Reading of Motherhood Identities in East African and Indonesian Literature
}

\author{
Stanley Elias \\ Department of Literature, University of Dar es Salaam, United Republic of Tanzania \\ Email: stanleyelias86@yahoo.com
}

\begin{abstract}
The study comparatively examines the representation of motherhood identities and the trauma of being childless to women in African and Indonesian literary texts namely Ngugi wa Thiong'o's Secret Lives and other Stories, Elieshi Lema's Parched Earth, Ratih Kumala's Genesis and Iwan Setyawan's Ibuk. Central to the analysis of this study is the argument that the existing cultural and religious discourses significantly contribute to the ways motherhood identities are construed in the society. Of a particular note, motherhood is argued to be a desired position that every woman wants most and is ready to sacrifice for it. Importantly, marriage, religious orientations and orders of the patriarchy certify motherhood and its related identities in the society. On the other hand, childlessness or failure to bear a male child circumscribe women in reduced forms of their identities and so subjects them to psychological and physical trauma and of course a social stigma.
\end{abstract}

Keywords: motherhood; childlessness; East African literature; Indonesian literature

\section{INTRODUCTION}

Motherhood assumes different meanings in contexts of varying cultures. In many societies around the world, motherhood is often bound to either cultural or religious meanings (Akujobi 2011). This means that the cultural meaning of motherhood is often conceived along with the social perception of what it takes to be a mother. Religious wise the meaning of motherhood is explained in relation to what is practiced in faith of a particular society towards motherhood. So such cultural and religious discourses in which motherhood is configured endorses meanings, ideologies and social relations towards women in the societies. Thus, motherhood has often been understood as an experience and institution which is shaped, manipulated and enforced by culture, religion and social context across space and time (Abasili, 2011; Hollos, M \& Larsen, 2008; Malone, 2013; Rich, 1976). This paper offers a critical comparative analysis of motherhood identities and childlessness in selected African and Indonesian literary texts. ${ }^{1}$
The analysis of this study is framed around a couple of ideas. First, it focuses on how authors Ngugi wa Thiong'o's Secret Lives and other Stories, Elieshi Lema's Parched Earth, Ratih Kumala's Genesis and Iwan Setyawan's Ibuk represent women desire and/or pride of motherhood. Here, it explores the fictional representation of the main characters in the texts and their quest or pride of being mothers. Secondly, the study discusses the traumatising experience and/or the social stigma that female characters go through when they fail to bear or are deprived of their children. In the latter objective, the paper examines how childlessness subject women under traumatising experience and/or social stigma within and outside their households.

This study is contextualised in works of first and third generations of writers of African literature, particularly East African writers and that of Angkatan $2000 s$ (2000s generation) of the contemporary Indonesian literature. This study supposes different works across 
generations of different political and cultural landscapes evolved from different political, economic, social and cultural forces and therefore have significant contribution to the (re)configuration on the motherhood identities.

To critically analyse the representation of motherhood, this study draws upon several feminism viewpoints relevant to the understanding of motherhood in Africa and Indonesia. It first locates the analysis within African feminism whose understanding of motherhood places women as primary mothers. Here, the analysis draws upon Alice Walker (1984) critique of western feminism on the understanding of African motherhood. According to Walker (1984) western feminism entails universality in understanding of motherhood and so she proposes the use 'black womanism' to appropriately understand African motherhood. For Walker (1984) black womanism entails transformations on racial identities, social status and sexual orientations as ascriptive of gender making and remaking relationships in societies. Walker (1984) asserts that African women are culturally mothers and childbearing and nurturing are traditionally ascribed to them. Importantly, the present study shows how is Walker's assertion that African women are culturally mothers fits the fictional representation of motherhood in African literary texts. The study also explicates Flora Nwapa's observation on the quest of motherhood among African women and how does the society construe childless women when they fail to bear children or by the time when they are deprived of their children. Nwapa (2011) says that 'the desire to be pregnant, to procreate is an overpowering one in the life of the woman. She is ready to do anything to have a child, be she single or married (p.532)'. In the analysis the study argues how is motherhood aspired, fought for and envisaged by African women.

In analysing the representation of motherhood in Indonesian literary texts, the study contextualises it within feminist scholarship in Indonesian settings. According to Arivia and Subono (2017) feminism in Indonesia has among other things tended to integrate feminism and other social factors. In similar view Hermansson (2014) adds that Islam has a significant contribution on the way women are viewed through feminism viewpoints. For Islamic discourses, feminism scholarship in Indonesia would look like movements to oppose discriminatory practices against women(Arimbi, 2009; Arivia \& Subono, 2017; Bennett, 2012; Blackburn, 2007; Qibtiyah, 2012). Arimbi (2014) in Finding Feminist Literary Reading: Portrayals of Women In The1920s Indonesian Literary Writings points that while women in 1920s would still be trapped in the patriarchal social web, so far trends show significant progress that they are not passive to patriarchal practices. That is to say significant efforts among women and other interested parts have brought about changes as women still struggle to unchain from persisting discriminatory and oppressive male practices. Of course, in the analysis of Indonesian literary texts, the study explores the ways in which cultural and religious discourses define motherhood.

As pointed earlier, motherhood is often placed within the cultural and religious meanings of many societies. This study argues whether cultural or religious is motherhood, many African and Asian societies often perceive, contemplate and conceive it in relation to procreation and the ability to nurture. 'The begetting of children is a social and religious duty attached to marriage and is vital to it'(Abasili,2011, p.555). Consequently, most of these societies would often define a woman by children she bears. Similarly Riessman (2000) and Papreen, Sharma, Sabin, Begum, Ahsan, Baqui (2000) observe that, bearing and rearing children receive central importance to women's power and general well-being of many Asians societies of different faiths. Of course, in all cosmologies $^{2}$ of African and Asian societies, it is often believed that a woman will attain her full womanhood when she is able to bear children (Fortes, 1978; Kanu, 2012). Ware (1978) adds that, besides individual gains that a wife and husband get from children, childbearing is also prioritised in political, religious, economic and kinship institutions. It can be argued that not only has childbearing become a personal wish but also a community obligation that married couples are obliged to(Fortes, 1978; Ware, 1978; Suggs, 1993; Papreen,et al, 2000; Riessman, 2000; Abasili, 2011; Bennett, 2012; Kizito, 2016). In a point of fact, childbearing ensures family and generational continuity, offers economic labour and fulfills religious demands in the community. ${ }^{3}$ As a result, almost every woman in African societies would aspire to enter such a social, sacred and powerful spiritual path of motherhood to secure dignity and her full womanhood(Abasili, 2011; Akujobi, 2011; Basden, 1966; Ngcobo, 2007; Nwankwor, 2012).

Bennett (2012) on the other hand finds that motherhood is women's primary role in many Indonesian societies. This primary role to women places them at fore as mothers in the society. Moreover Bennett (2005) explains that from their primary role, Indonesian women are often expected not only to become mothers, but also to plan having good families for their good nation as well. This confirms that childbearing in African and Asian societies has become a social, political, religious and economic obligations and so does Indonesian 
motherhood. For example, Dzuhayatin (2002) identifies that the Indonesian motherhood is often perpetuated through political, economic and social discourses and more importantly religious discourses. For instance within Indonesian conservative Islamic discourses to mention a few, Muslims are encouraged to marry and get children (Bennett, 2005; Dzuhayatin, 2002; Silalahi \& Setyonaluri, 2018). In so saying it can be argued that, the value of childbearing in Indonesian community extends beyond the married couples to national, religious and cultural wants. Fortes (1978:125) puts it that in societies where motherhood is placed as a primary role, the begetting of children is regarded as a sine qua non ${ }^{4}$ for a full womanhood and all women and men aspire to attain it.

On the other hand, a woman who fails to get children within a reasonable period after the marriage is likely to receive the extremes of physical, psychological and social abuse from her husband as well as from the community. Hollos and Larsen (2008) point out that, regardless of causes, childless women will often suffer personal grieves, social stigma and ostracism and in some cases they are likely to undergo economic deprivation. According to Goffman (1963) these childless women are 'reduced in the eyes of others from whole and usual person to a tainted and discounted one'(p.3). Not having children implicates a 'social failure' and more importantly it has been inciting a sense of being incomplete among individual particularly women in the society. Papreen et. al (2000) further articulates that;

'Not having children results in a sense of role failure with social and emotional consequences for both men and women. This can often result in social stigmatisation of the couple and particularly of the women concerned. Within the household, childlessness may also mean physical and psychological abuse for women' (p.33).

Of a particular note Nwankwor(2012), (Kizito, 2016), Wakota (2014) and Papreen et. al (2000) argue that because of prevailing gendered ideologies in societies, women are often placed as faulty when the couples are childless. Indeed, such gendered ideologies in the society reduce women to incapacitated and incomplete beings and so all the social shames, bigotry and scorn become part and parcel of their lives.

\section{DISCUSSION}

Ngugi wa Thiong'o was born in Limuru- Kenya in 1938. He was educated in Kenya and Uganda and later in the United Kingdom. Thiong'o sprung into literary fame after he had staged his first play The Black Hermit in 1962 in Kampala, Uganda. According to Thiong'o (1975) "the stories in the collection form[ed] his creative autobiography over the last twelve years and touch on ideas and mood affecting him over the same period"(preface). As of this reason Secret Lives and Other stories is considered as his debut literary project in early 1960s (Mwanzi, 1995).

Importantly, like many other African writers, Thiong'o' Secret Lives and other stories is shaped by moments of autobiographical histories of his ancestral home Kenya, cultural richness, colonialism and neocolonialism and state of politics(Gikandi, 1989; Petersen, 1981). For ("The struggle of values in 'Secret Lives'| The Herald," 2014) the tales in the collection are metaphorically and compellingly representing man's travails against the nature, African histories, motherhood and childlessness, dispossession of humanity and power, colonialism and neo-colonialism. Secret Lives and other stories is in three parts namely "Of Mothers and Children", "Fighters and Martyrs" and "Secret Lives". Each part consists of several stories that reflect the thematic concern of the respective part. This study particularly analyses the representation of motherhood and the social prejudice to childless women in the "Of Mothers and Children" with three stories namely 'Mugumo', 'And the Rain Came Down' and 'Gone with the Drought'.

Situated in African traditional settings, "Of Mothers and Children" offers an opportunity to imagine on how cultural set ups in traditional African societies place women as primarily mothers. Mukami, Nyokabi and Old Woman in the three stories 'Mugumo', 'And the Rain Came Down' and 'Gone with the Drought' respectively aspire to become mothers as it underscores their acceptability and recognition in the society. According to Ngcobo (2007) and Akujobi (2011) for Mukami, Nyokabi and Old woman becoming a mother is privileged and the uppermost position which every woman would like to attain because she will be attentively accepted by the husband, in-laws and the entire society.

In the story of 'Mugumo' in particular, Mukami struggles to get a child who would stop her from being physically and psychologically abused by her husband and co-wives and of course to strengthen her marriage which had started shaking. 'But she resolutely refused to let such beating and misgiving subdue her will' (8). Because of not having a child of her own, Mukami is determined to do anything to have a child as Nwapa (2011) finds that the desire to procreate subjects an African woman to do anything to have a child, be she single or married (p.532). Mukami travels to the sacred Mugumo tree to 
meet Mumbi. ${ }^{5}$ Upon meeting Mumbi, Mukami’s womb gets touched ' $[\mathrm{A}] \mathrm{nd}$ then she knew-that she was pregnant, had been pregnant for some time' (8). Though the story might be suggesting the spiritual solutions that Mukami sought in order to get a child, yet it is implicative to lives of African women in traditional settings where access to modern medical services is by far real. So to say the author uses 'Mugumo' as a narrative trope to suggest the power of beliefs and spirits which members of the societies together still hold. Mumbi on the other hand is suggestive of spiritual and loving power embedded in African motherhood.

On the other side Nwankwor (2012); Ngcobo(2007); Malone (2013); and Nwapa (2011) explain that it becomes traumatising and a burden when a woman becomes childless. Consequently, as Papreen et. al (2000) point out that, a childless Mukami is abused physically and psychologically from within and outside the household.

'Two seasons, three seasons, and the world she knew began to change. She had no child" (4). ....."The beating; the crowd that watched and never helped! But that was a preamble to such torture and misery that it almost resulted in her death that very morning' (p.5).

Here, there is a point of convergence between Mukami's torture and the crowd watching without helping. Most notably the story of 'Mugumo' represents patriarchal ideologies that subjugate women and place them as faulty when the couple is childless. To the crowd, Mukami is 'reduced in the eyes of others from whole and usual person to a tainted and discounted one' (Goffman, 1963,p.3). So for the crowd standing and watching when Mukami is being beaten and tortured conforms to patriarchal and gendered ideologies that often place women as faulty and bearer of all social blames.

In the story of 'And the Rain Came Down' Njeri and Nyokabi represent two contrasting figures central to African motherhood. Njeri loses her child in the forest and later keeps running all over the ridge in search of the child. It is always believed that being an African mother entails moral transformations and acceptance of responsibilities (Akujobi, 2011). For Njeri to lose her child in the forest signals irresponsibility for a mother and it was not expected to let it happen in her own hands. Therefore, it can be argued that Njeri lacks sense of selfsacrifice which is central to African motherhood. On the other hand Nyokabi is childless. She desires to have had children to accomplish her womanhood. 'Nyokabi's expectations had been many. But their unvarying centre had always been 'so many' children. Ever since her initiations, she had one desire, to marry and have children' (p.10). Nyokabi believed children would complement her womanhood in her old age and give her pleasure in her marriage. Nyokabi believes children compliment a woman to the desired position of motherhood. Of course the belief corroborates with Makinde (2004) who says that children compliment a woman to the 'golden post' of motherhood in marriage especially at old age. ${ }^{6}$ That is to say, having children at old age, Nyokabi would have accomplished what every married woman in many African cultures aspires. Nyokabi had got a husband of her dreams but she didn't have children to fulfill her desire. 'She had got her man the kind of husband she had wished for, but...but... Murungu ${ }^{7}$ had not sent her anything. He had not answered her cry, her desire, and her hope. Her great expectations had come to nought' (p.10). Subsequently, Nyokabi becomes frustrated because of being childless. As a result of such frustrations and of course, social stigma, Nyokabi hates all women who are having children in her society. Nyokabi journeys to the Mugumo tree to meet Mumbi. Unlike Mukami in the story of 'Mugumo', here, Nyokabi does not conceive a child but rather she picks up a baby who was crying in the forest helplessly.

Alluding the historic drought and famine that affected Kenya in 1961/1962 the story of 'Gone with the Drought' presents the trauma of an old woman who loses her child because of drought and hunger. Thus, the story of 'Gone with the Drought' presents an opportunity to imagine what Neil (1962) and Speranza, Kiteme and Wiesmann (2008) find to be 'the disastrous zonal problems of famine in Kenya in 1961' to women. Set at near past, the story journeys to the loss of her other two children and a husband during the 'famine of cassava' of $1961 .^{8}$

'To her this night of 1961 was so different from such another night in the 40s when two of her sons died one after the other because of drought and hunger. That was during the 'Famine of Cassava' as it was called because people ate flour made from cassava' (p.18).

The old woman becomes childless because all of her children died because of drought and hunger. The old woman becomes widowed and childless. In the contrary of what Nwapa (2011:p.532) says '[S]he is ready to do anything to have a child', here, an old woman cannot do anything to get a child because she had lost her husband and all of her children. The desire to have children of her own is 'gone' with drought and hunger. Consequently, an 
old woman becomes traumatically depressed because of losing her children and her husband. These all happen at the age when the old woman cannot bear children. 'Now she looked up and continued, 'I am an old woman now. The sun has set on my only child; the drought has taken him. It is the will of God' (p.19). According to the old woman at her age she leaves that to the will of God. Her expectation to enjoy the 'golden position' of motherhood in the society is tragically emptied by the drought and hunger.

Generally, the metaphorical usage of barrenness, rain and drought in the three stories signals the social and cultural burden ascribed to women and mothers. Women in the story of 'Mugumo' and 'And the Rain Came Down' struggle to circumvent the societal expectation by doing anything to become mothers. The need of children overpowers the entire life of a woman in the society. It is a privileged status that every woman need to have as it empowers them and underscores the family and social respect. In the third story 'Gone with the Drought' uncontrollable force deprives the 'golden position' of a woman. The drought signals a burden and trauma to an old woman at old age as she cannot fight back for motherhood. Central to the three stories it can be argued that, the life of a woman is all about having children and childlessness is a burden that places women at ' rejectbeings' within the household and in the society.

Elieshi Lema was born in Tanzania in 1949. She is a novelist, poet and a publisher writing both in Swahili and English language. According to Wakota (2014) Elieshi Lema occupies central position in Tanzanian literature in English. She is considered as the most renowned Tanzanian women writing in English(Wakota,2014). Her novel Parched Earth (2001) is argued to offer vantage point to understand gender relations of the Tanzanian modern generation. Importantly, the novel represents and deconstructs orders of patriarchy that inform every aspect in which male and female relates in life. According to Ng'umbi (2015) Lema critiques of patriarchal system feature in both of her works where she often presents a single-parent family as a means of subverting male power-dominance in the family. In fact, her incisive attack on patriarchy and empowering of women through fiction remains central in Parched Earth (Wakota, 2014; Kweka, 2015; Ng'umbi, 2015).

Central to the novel is the narratives of Doreen, Foibe Seko and Great Aunt Mai and their survival experience in the orders of patriarchy. For Lema (2001) these characters among other things have to avow their identity as rational and 'able- beings' in the 'social web' as opposed to the social and cultural expectations placed on women. In Parched Earth the analysis explicates the ways in which orders of patriarchy conceive motherhood and how do the orders victimise women in the institution of motherhood. Here, the focus of the analysis is on the Doreen's and Foibe's experiences with the patriarchy and how do the orders of patriarchy subject them into 'incomplete being' despite the fact that they bear children. The study particularly argues on the ways in which the social web creates social expectation that women are expected to accommodate. Through the social expectations as per the 'social web', both members of the society are expected to conform to their assignments. ${ }^{10}$

In the foremost, Parched Earth provides an avenue to imagine ways in which orders of the patriarchy place women as nurturers and child bearers in the society. As nurturers ' $[\mathrm{W}]$ omen nurture the earth like they do children and husbands' (p.12). As for this reason, patriarchy demands women to procreate and nurture. Customs and orders of patriarchy have ascribed women with procreation as to conform to the social expectation and win their husbands love. Doreen says 'She got married to a shopkeeper, had five children and become accordingly fat as required by customs' (p.14) to win their 'husband's heart' (p.72). In similar way, Doreen and Patrick had planned to have four children as to conform to what the society expects from them. Doreen believes children would give her security of her marriage as well as joys of motherhood. 'We wanted four children, two girls and two boys, a bigger house than the one Martin already had and a big farm where we could grow things and keep animals so I would not miss home'(p.69). Doreen is joyful as she bears Milika. Milikas' birth is celebrated not only by her mother but also the father. Soon as Martin realises that Doreen is pregnant, he celebrates as if it had signaled assured fertility in both of them.

As Ngcobo (2007), Emecheta (2011) and Nwapa (2011) point out that the primary purpose in African marriages is to procreate, Doreen and Martin plan to have four children. $\mathrm{Ngcobo}(2007)$ points that "As elsewhere, marriage amongst Africans is mainly an institution for the control of procreation. Every woman is encouraged to marry and get children in order to express her womanhood to the full". (533). For Doreen, children would mean to be in her fullest form within the household and in the entire society. For Martin children would express his fullest form of manhood and as for patrilineal Martin was, children would mean assured continual of family lineage of his generation. However, Emecheta (2011) notes that 'A woman earns more respect if she bears male children' (p.556). That, a fullest form of both motherhood and manhood is expressed when a woman bears a male 
child. Emecheta (2011) and Makinde (2004) assert that in many African societies women are obliged to bear a male child so as to earn authority within and outside the family. Emecheta (2011) stresses that "Male children are very, very important." (p.556). In this regard Doreen is not safe in her family as she is yet to give birth to a male child. This is followed by Martin deserting her as she has failed to give her a male child. So Milika never quenched Martin's desire to have a child as he wanted a male child. Martin wants to comply with the orders of social web that have in turn formed social expectations that prefer male child over female child. As of this reason both men and women become slaves of the social web. According to Emecheta (2011) many African women; “... would like to have a male -child, who will not be married away, but will stay in the family home and look after his mother when she becomes weak and old" (p.556). Chukwuma (1990) adds that a woman is ' a facile lacklustre human being, the quiet member of a house-hold, content only to bear children, unfulfilled if she does not and handicapped if she bears only daughters' (p.131). Thus, Doreen's failure to bear a male child is considered handicapped and 'childless'. Martin abandons her and goes for another woman.

Also Parched Earth provides an avenue to examine Papreen's et al (2000) findings that uneven gendered relationships between men and women in the societies have significantly contributed to subject women as faulty in every aspect of life. Doreen is blamed for not bearing a male child. According Papreen's et al (2000) gendered ideologies in many societies have made women as bearers of problems in marriages including infertility. Doreen says;

'I refused to take the blame. I refused to be a scapegoat. My body felt fecund, warm, and secretive. I told him so and I tried to discuss the situation in a different way, reminding him of what the doctor had told us. He was silent' (p.149).

Though Doreen is reluctant to accept the blames of such infertility as she keeps reminding him on what the doctor had said about it, she argues Martin to discuss the problem in different way but not pointing at her as a source of the problem. Doreen is blamed for not conceiving for a long time in spite of what the doctor had advised them. Nwankwor (2012) observes that in most cases women will receive all the blames even when they are not a source of the problem.

Parched Earth also presents another way to critique ways of 'social web' which have created social expectations that women and men need to conform.
Contrary to Nwapa (2011) who says a woman would do anything to get a child, Parched Earth presents marriage as an institution that certifies motherhood in the society. Foibe is cursed and considered immoral after having an affair with a married man and becomes pregnant. Foibe gives birth to Godbless without being married and subsequently she is expelled by her father and goes to live with Great Aunt Mai. In the society where Foibe lives, getting a child outside marriage is considered immoral and therefore Foibe has violated the values of the society. Foibe's motherhood is not acceptable as she has attained it outside the marriage system. She becomes rejected by the parents, her partner and the society not because they never loved each other but it is the social demands that the social web has endorsed to its members.

As pointed out earlier this study also focuses on Angkatan $2000 \mathrm{~s}^{11}$ of Indonesian literature. Specific to this study, Angkatan 2000s is used inclusively of the contemporary women and men writers who started writing in 2000s regardless of other classifications that these writers may belong. Most of the works of the Angkatan $2000 \mathrm{~s}$ are characterised by modernity and dynamics of social and political landscapes, romanticism and religious subjectivities and most importantly women's subjectivities of the contemporary Indonesia. Of course, Ratih Kumala and Iwan Setyawan are young and vibrant writers of the recent time of contemporary Indonesian literature. Ratih Kumala was born in Jakarta in 1980 and Iwan Setyawan was born in Malang in 1974. Both Kumala and Setyawan belong to the Angkatan 2000s lof the Indonesian literature. As for Arimbi (2009) Kumala would fit to be categorised in Sastrawangi generation('fragrant literature') and Ismah (2011) in chick lit to refer to all women writers who emerged after Soeharto and in 2000s eras respectively. Sastrawangi was used stereotypically to refer to group of writers from 'urban, middle class, young, educated female writers'(Danerek, 2006,p.13). Ratih Kumala has authored other four books namely Tabula Rasa, Larutan Senja, Kronik Betawi and Gadis Kretek(cigarrete girl) and many scripts for television dramas besides Genesis which this study looks at. Iwan Setyawan is well known for 9 Summers 10 Autumns, Melankoli Kota Batu and Ibuk.

Published in (2005) Kumala's Genesis looks at contemporary women's struggle in a conditioned religious orientations and patriarchal society. Importantly, katolik (catholic) orientations constitute ways through which members of the society construe on how women can attain and enter motherhood. In the novel Pawestri who becomes pregnant at 19 years old before marriage is expelled by his father from his family because she does 
conform to the katolik religious ways which circumscribe a rite to motherhood. While scholars like Papreen, et al (2000); Riessman (2000) and Bennett (2012) would view pregnancy as a sign of hope to a woman and so celebrated by the family members, here, it is a burden to woman which subsequently brings tragedies to Pawestri. Because of pregnancy Prawestri is victimised by being expelled from home and banned from family membership.

'Laki-laki angkuh itu lalu pergi entah ke mana, meninggalkan aku yang tengah berbadan dua. Pada saat yang sama diusir pula aku dari rumah. Aku bukan lagi anak, jelas bukan isteri orang. Aku hanyalah: perempuan'(Kumala 2005,p.11).

[The arrogant man then went somewhere, leaving me in the middle of two body. At the same time, I was expelled from home. I am no longer a child, obviously not person's wife. I'm just a woman]

It is worth arguing that religious values in Prawestri's society not only influence the life of a woman but also provide ways through which motherhood is conceived and most importantly ways in which motherhood is accepted in the society. The practiced katolik values have set acceptable standards for women to enter motherhood and anyone who violates these standards is banned from family membership and society as well. According to Arimbi (2009) religious discourses in Indonesia have set parameters from which women are located and defined. Such religious discourses together with existing ideological constructions in fact provide a definition of motherhood and identities of women as it is for Prawestri.

The ousting of Prawestri from the family provide another opportunity to critique the patriarchal orders that determine social relations between men and women in the contemporary Indonesia. While Prawestri's mother is not consented to such ousting of her own daughter, she is socially entitled to obey whatever his husband decides. 'suster, aku telah menelantarkan anakku. Aku tak berani membantah suamiku yang menganggap anak perempuanku yang nomor satu tidak ada'(Kumala 2005, p.5) [Sister, I have abandoned my child. I dare not argue that my husband thinks, my number one daughter is not there]. As of the orders of patriarchy in this society, Prawestri's mother is conditioned not to argue against her husband in spite of not willing to let her daughter be expelled from the family.

As of this Prawestri's mother ends up depressed and mentally disordered because of being deprived of her child. She keeps recalling what she had previously advised Prawestri.
'Kadang ibu berteriak marah pada dirimu. Memperingatimu agar jangan bermain gunting, jangan dekat-dekat kompor, jangan keluar terlalu sore sebab tak baik bagi anak perempuan. Seingatku, ibu bahkan tidak pernah menasehatimu sebegitu rupa saat kau masih benar-benar ada di rumah ini'(Kumala 2005, p.105).

[Sometimes a mother cries angrily at you. She warns you not to play scissors, don't get near the stove, don't get out in late evening because it's not good for girls. As I recall, mother never even advised you in such a way when you were really in this house.]

According to Arimbi (2009) and Akanle, Adesina and Nwaobiala (2018) patriarchal discourses circumscribe the ways women and men relate in the society and so such discourses have conditioned Prawestri's mother to remain silent and accept whatever his husband decides for Prawestri.

On the other hand Genesis presents an opportunity to imagine the trauma of losing a child to a woman. Prawestri's mother is dispossessed of her own child because of conforming to religious and patriarchal orientations. As a result, she becomes depressed because of holding pains of losing her daughter. 'Akhir-akhir ini ibu jadi lebih sedih. Rindunya pada Pawestri mulai tidak dapat dibendung. Di antara ketakutannya pada bapak, ibu mulai menciptakan dramanya sendiri'(Kumala, 2005, p.93) [ Lately mother became more sad. Her longing for Pawestri began to be unstoppable. Among the fears to the father, the mother began to create her own drama]. For Irmadani (2010) Prawestri's mother suffered prolonged depression that made her unable to do anything because she had lost her daughter. She finally ends to Rumah Sakit Jiwa [mental hospital].

On the other hand, Prawestri who later joins Catholic as Sister Maria Faustina (as a nun) has had her child taken away from her and she never knew where he (child) was sent. It was until when they met in Ambon while his son was working as volunteer. Like her mother, Prawastri had bad ending. She first was deprived of her motherhood as her child was secretly taken away and was given to another woman (Sawitri) who willingly accepted to offer her womb in order to bear Prawestri's child. Following this, Prawestri had an opportunity to join Catholic as a nun. She later opted to join the mission in Ambon during the religious misunderstandings between Muslim and Christians where she meets her son who worked as a volunteer in the mission. Secondly, Prawestri becomes injected with sedative liquid by the 
security forces which subsequently kills her slowly so as to interfere the testimony of the massacre that Sister Maria Faustina had witnessed. She ends in coma and later dies. Generally, it can be argued that religious and patriarchal orientations dictate social relations of men and women within and outside their families. Hence, Prawestri's mother remains mutedly supportive of her husband decisions as dictated by such orientations though she inwardly bears pains of being deprived of her child.

Iwan Setyawan's Ibuk was published in (2012) and it appears in Indonesian language. Ibuk presents an opportunity to explore and critique Magret Atwood's (1985) configurations of motherhood under the selfsacrificing character in attending matters relating to children. In the novel, The Handmaid's Tale, Atwood represents women on the basis of men's desires. Of a particular note, men suppose women to silently learn with all subjugations as they shall be saved through childbearing. At the age of 17 years old, Tina is advised to marry as required by the traditions and Islamic teachings. Her grandmother, Mbak Pah whom she stays with, advises her to get married as time is rushing and she needs to have children. She finally gets married to an angkot driver (a driver of mini bus for public transport), Abdul Hasyims (Sim, hereafter). They are blessed with five children namely Isa, Nani, Bayek, Rini and Mira. With all these children, it is meant increased responsibilities to parents. While Rinaldi (2017) and Julie Gunlock (2017) opine against the assumption that motherhood is self -sacrificing, yet they acknowledge that a woman is expected to sacrifice her everything including her time, wealth, ambitions and sense of self to a higher purpose, one more worthy than her own individual identity to her children. Tina spends everything she has to make sure her children get good education, dress properly, eat well and feel loved despite life hardship the family encounters. She even borrows money from Mang Udin (a credit man) who later takes all kitchen utensils in return of what Tina had borrowed. Tina sacrifices everything for her children. Of course, Ibuk at some point provides an avenue to imagine what Rinaldi (2017) reframes about motherhood as not a sacrifice but a privilege. Despite the fact that the family lived poor life, Tina and Sim are proud of having their children especially of their only son Bayek. Tina never complains about child rearing but she feels concerned and proud of having them and more especially when they are happy and satisfied.

It is also not surprising that the Setyawan's Ibuk would be argued to perpetuate patriarchy ideologies under self-sacrificing motherhood. Of all the children, Tina had devoted much of her energy, time, passion and wealth to Bayek. As of this society boys are preferred to girls as it is believed they would look after the parents at old age. During her medical visitation for Bayek to Mbak Carik, Tina was told to look after the boys as they would change the family destinies. As of this reason Tina and her husband sold their angkot to send Bayek to the university. Again, the portrayal of Bayek as the only most successful child among others is suggesting on the social construction and expectations towards men and women in the society.

\section{CONCLUSIONS}

The cultural and religious discourses have been significant to provide motherhood identities in many societies. Of specific interest to this study has been the way motherhood identities are represented in African and Indonesian literary texts. This study focuses on the way the quest to enter motherhood overpowers the life of every woman in the African literary texts. As of the analysis, becoming a mother is considered a sacred and privileged position that women are certified into their full womanhood and so become full accepted citizens in the society. Importantly, the study argues for the place of gendered ideologies which inform every aspects of motherhood identities in the society.

The study argues that such gendered ideologies have created social expectations that women and men need to conform through motherhood. Of particular note, the study points that marriage is an institution that certifies acceptance motherhood in African societies. On the other hand, the study argues that childlessness or when a woman fails to bear a male child turns out to be a burden that subsequently traumatises women psychologically, physically and socially.

In the analysis of the Indonesian literary texts, the study argues that religious orientations and orders of patriarchy significantly provide ways in which motherhood identities are configured. Through religious and orders of the patriarchy women identities are provided including that of motherhood. The study argues on the selfsacrificing identity inherent to Indonesian motherhood. As of this reason, women are ready to sacrifice anything to attend matters relating to their children.

\section{ENDNOTES}

1) In this study African literature refers to texts of first and third generations. First generation African writers of which among others Ngugi wa Thiong'o falls in, are argued to be pioneers of the modern African literature. This generation has had their works started to emerge 
between 1950s and 1970s. Majority of these pioneers of African literature were born, raised and lived a greater part of their lives in colonial times and so their writings are politically and culturally influenced by their experience. They set their works in pre-colonial, colonial and post-colonial times to draw what was there before, what went wrong and their endeavors to bring about transformations and rewrite Africa which has had been misrepresented. Third generation of African writers in which Elieshi Lema falls in includes the younger writers who debuted into the field between 1980s and 1990s following the emerging political reforms that also ventured multiple discourses. As of this reason many writers of this generation co-opted literature as an instrument to protest and write about cultural and political reforms.

2) The term cosmology is used to mean the way societies construes, perceive, conceive and contemplate motherhood.

3) Helen Ware (1978) in Economic Value of Children in Asia and Africa: Comparative Perspectives presents competing arguments on childbearing in Africa and Asia. While children would be viewed as economic burden in some parts of Africa, some African societies would view children as economic labour to provide wealth for the family.

4) Fortes (1978) uses this Latinate term to mean an obligatory rite that women need to pass through to their completeness.

5) In Gikuyu culture (mythology), Mumbi is one of the first parents who lived in the top off the mountain and married to Gikuyu who was the first to arrive to the mountain.nMumbi as of this story is goddess to whom childless women seek deliverance on their barrenesss. Gikuyu mythology Mumbi is one of the first parents in Gikuyu. The first Gikuyu man and had walked to Mugumo tree (at the top of the 'Mountain of God' - Kiri Nyaga) and married Mumbi who was living there. As of this story Mumbi is a god of creation and a molder to whom women sufferings would be resolved.

6) Makinde (2004) explains the conception of motherhood in Yoruba culture from which being a mother outstand the rest such as wifehood. For more details see Makinde (2004) 'Motherhood as a source of empowerment of women in Yoruba culture'. Nordic Journal of African Studies 13(2): 164-174

7) Murungu means God in Gikuyu language.

8) In the report that follows the "Famine and Floods in Kenya, 196I" says that the disastrous floods of 1961 had made famine relief distribution very much more difficult and as a result it affected the life of people including deaths of people.
9) According to the story of Parched Earth both men and women are trapped in patriarchy system which is like a social web that affects both in every aspect of life. The novel deploys the 'spider web' analogy to explicate the ways in which orders of patriarchy victimizes both male and female despite the assumption that it is malefavouring system and so they become beneficiaries of it.

10) The socially constructed duties as per gender relations.

11) Angkatan 2000s refers to literary generation of $2000 \mathrm{~s}$ which is characterized by modernity, vulgarism in language use, dynamics of social and political landscapes, romanticism and religious subjectivities and of course increase of cyber literature.

\section{REFERENCES}

Abasili, A. I. (2011). Seeing Tamar through the prism of an African woman: A contextual reading of Genesis 38. Old Testament Essays, 24(3), 555-573.

Akanle, O., Adesina, J. O., \& Nwaobiala, U. R. (2018). Turbulent but I must endure in silence: Female breadwinners and survival in Southwestern Nigeria. Journal of Asian and African Studies, 53(1), 98-114. https://doi.org/10.1177/0021909616658913

Akujobi, R. (2011). Motherhood in African Literature and Culture Motherhood. CLCWeb: Comparative Literature and Culture, 13(1), 1-7.

Arimbi, D. A. (2009a). Reading Contemporary Indonesian Muslim Women Writers:Representation, Identity and Religion of Muslim Women in Indonesian Fiction. Amsterdam: Amsterdam University Press,.

Arimbi, D. A. (2009b). Reading Contemporary Indonesian Muslim Women Writers - Representation, Identity and Religion of Muslim Women in Indonesian Fiction. https://doi.org/10.5117/9789089640895

Arivia, G., \& Subono, N. I. (2017). A Hundred Years of Feminism in Indonesia An Analysis of Actors, Debates and Strategies.

Atwood, M. (1985). The Handmaid's Tale. Toronto: McClelland \& Stewart.

Basden, G. (1966). Marriage among the Ibos of Nigeria. London: Frank Cass and Co. Ltd.

Bennett, L. R. (2005). Women, Islam and Modernity: Single Women, Sexuality and Reproductive Health in Contemporary Indonesia. London: Routledge.

Bennett, L. R. (2012). Infertility, Womanhood and Motherhood in Contemporary Indonesia: Understanding Gender Discrimination in the Realm of Biomedical Fertility Care. Intersections: Gender and Sexuality in Asia and the Pacific, (28).

Blackburn, S. (2007). Women and the State in Modern Indonesia. Cambridge, UK: Cambridge University Press. 
Chukwuma, H. (1990). Voices and Choices'Literature and Black Aesthetics. (C. Emenyonu, Ed.) (Ed).

Danerek, S. (2006). Tjerita and Novel: Literary Discourse in Post New Order Indonesia (1st ed.). Lund.: Centre for Languages and Literature, Lund University.

Dzuhayatin, S. (2002). Role expectation and the aspirations of Indonesian women in socio-political and religious contexts. In S. S. and M. Q. S. M. Atho Mudzhar, Sijida S. Alvi (Ed.), Women in Indonesian Society: Access, Empowerment and Opportunity (pp. 154194). Yogya: Sunan Kalijaga Press.

Emecheta, B. (2011). Feminism with a Small 'f'!' In African Literature: An Anthology of Criticism and Theory. (T. Olaniyan and A.Quayson, Ed.). Oxford: Blackwell Publishers Ltd.

Fortes, M. (1978). Parenthood, marriage and fertility in West Africa. Journal of Development Studies, 14(4), 1211-149.

Gikandi, S. (1989). On culture and the state: The writings of Ngugi wa Thiong'o. Third World Quarterly, 11(1), 148156. https://doi.org/10.1080/01436598908420144

Goffman, E. (1963). Stigma: Notes on the management of spoiled identity. Englewood: Prentice Hall.

Hermansson, S. (2014). Gendered work and power relations in Indonesian NGO : s A qualitative study from two organizations in Java. Lund.

Hollos, M \& Larsen, U. (2008). Motherhood in sub-Saharan Africa: The social consequences of infertility in an urban population in northern Tanzania. Culture, Health \& Sexuality, 10(2), 159-173.

Ifejika Speranza, C., Kiteme, B., \& Wiesmann, U. (2008). Droughts and famines: The underlying factors and the causal links among agro-pastoral households in semiarid Makueni district, Kenya. Global Environmental Change, 18(1), 220-233. https://doi.org/10.1016/j. gloenvcha.2007.05.001

Irmadani, F. (2010). Gangguan Kejiwaan Tokoh Ibu Dalam Genesis | Irmadanifitri. Retrieved November 3, 2018, from https://irmadanifitri.wordpress. com/2010/10/10/gangguan-kejiwaan-tokoh-ibudalam-genesis/

Ismah, N. O. R. (2011). The New Generation of Women Writers from the Pesantren Tradition in Indonesia. EXPLORATIONS a Graduate Student Journal of Southeast Asian Studies, 11(1), 105-120.

Julie Gunlock. (2017). IWF - Parenting: Sacrifice or Privilege. Retrieved November 5, 2018, from http:// www.iwf.org/blog/2804491/Parenting:-Sacrifice-orPrivilege

Kanu, I. A. (OSA). (2012). The Dimensions of African Cosmology. Filosofia Theoretica: Journal of African Philosophy, Culture and Religion, 2(2), 533-555.

Kizito, L. (2016). Pain of childlessness to African women. Retrieved August 16, 2018, from https://www. standardmedia.co.ke/health/article/2000198801/ pain-of-childlessness-to-african-women

Kumala, R. (2005). Genesis. Yogyakarta: Insist.

Kweka, E. C. (2015). An interview with Elieshi Lema : Life of a woman. International Journal of English language, Literature and translation studies, 2(3), $1-6$.

Lema, E. (2001). Parched Earth: A Love Story. Dar es Salaam: E \& D Limited.

Makinde, T. (2004). Motherhood as a source of empowerment of women in Yoruba culture. Nordic Journal of African Studies, 13(2), 164-174.

Malone, E. B. and C. (2013). Female Circumcision and Motherhood. Retrieved August 14, 2018, from https://blog.uvm.edu/vlbrenna-rel163/sexualitymotherhood/

MR. T. NEIL, C.M.G., T. D. (1962). Report on famine relief in Kenya in 1962. Nairobi.

Mwanzi, H. O. A. (1995). 'The Style of the Short Story in Kenya :An Analysis of the Short Stories of Ngugi wa Thiong'o, Leonard Kibera and Grace Ogot. University of Nairobi.

Nahar Papreen, Anjali Sharma, Keith Sabin, Lutfa Begum, S. K. A. and A. H. B. (2000). Living with Infertility: Experiences among Urban Slum Populations in Bangladesh, 8(15), 33-44.

Ng'umbi, Y. (2015). Politics of the Family in Contemporary East and West African Women 's Writing.PhD Thesis Stellenbosch University.

Ngcobo, L. (2007). African Motherhood-Myth and Reality', African Literature: An Anthology of Criticism and Theory. U.S.A: Blackwell Publishers Ltd.

Nurbaya, S., \& Asuhan, S. (2014). Finding feminist literary reading: Portrayals of women in the 1920s Indonesian literary writings, 148-162.

Nwankwor, C. C. (2012). Childlessness in Flora Nwapa ' $S$ One Is Enough and Femi Osofisan 'S Wuraola, Forever. University of Nigeria, Nsukka.

Nwapa, F. (2011). Women and Creative Writing in Africa. African Literature: An Anthology of Criticism and Theory. (T. Olaniyan and A. Quayson, Ed.). Oxford: Blackwell Publishers Ltd.

Petersen, K. H. (1981). Birth Pangs of a national consciousness: Mau Mau and Ngugi wa Thiong'o. World Literature Written in English, 20(2), 214-219. https://doi.org/10.1080/17449858108588679

Qibtiyah, A. (2012). Feminist identity and the conceptualisation of gender issues in Islam :Muslim gender studies elites in Yogyakarta, Indonesia Alimatul Qibtiyah Centre for the Study of Contemporary Muslim Societies, (March).

Rich, A. (1976). Of Woman Born: Motherhood as Experience and Institution. London: Virago.

Riessman, C. K. (2000). Stigma and Everyday Resistance 
Practices: Childless Women in South India, 14(1), 111-135.

Rinaldi, K. (2017, August). Motherhood Isn't Sacrifice, It's Selfishness. The New York Times. Retrieved from https://www.nytimes.com/2017/08/04/opinion/ sunday/motherhood-family-sexism-sacrifice. html?module=inline

Setyawan, I. (2012). Ibuk. Jakarta: Gramedia.

Silalahi, P. C. S., \& Setyonaluri, D. (2018). My Mother, My Role Model: Mother 's Influence on Women 's Fertility Intention in Indonesia. Malaysian Journal of Economic Studies, 55(1), 81-96.

Suggs, D. (1993). Female status and role transition in the Tswana life cycle. In D. S. and A. Miracle (Ed.), Culture and Human Sexuality. Pacific Grove: Brooks Cole Publishing.

The struggle of values in 'Secret Lives' | The Herald. (n.d.).
Retrieved October 4, 2018, from https://www.herald. co.zw/the-struggle-of-values-in-secret-lives/

Thiong'o, N. (1975). Secret Lives and other stories. London: Heinemann Educational Books.

Wakota, J. (2014a). The Making and Remaking of Gender Relations in Tanzanian Fiction.

Wakota, J. (2014b). The Making and Remaking of Gender Relations in Tanzanian Fiction. Stellenbosch.

Walker, A. (1984). In Search of Our Mothers 'Gardens. San Diego: Harcourt Brace Jovanovich.

Wanjiku, B., \& Kabira, M. (2007). Validating Women's Knowledge and Experiences: A Case Study of Wom en's Experiences and Food Security in Kenya.

Ware, H. (1978). Economic Value of Children in Asia and Africa: Comparative Perspectives. Determinants of Fertility in Developing Countries: A Summary of Knowledge, (50). 